

\section{DISCLAIMER}

This report was prepared as an account of work sponsored by an agency of the United States Government. Neither the United States Government nor any agency Thereof, nor any of their employees, makes any warranty, express or implied, or assumes any legal liability or responsibility for the accuracy, completeness, or usefulness of any information, apparatus, product, or process disclosed, or represents that its use would not infringe privately owned rights. Reference herein to any specific commercial product, process, or service by trade name, trademark, manufacturer, or otherwise does not necessarily constitute or imply its endorsement, recommendation, or favoring by the United States Government or any agency thereof. The views and opinions of authors expressed herein do not necessarily state or reflect those of the United States Government or any agency thereof. 


\section{DISCLAIMER}

Portions of this document may be illegible in electronic image products. Images are produced from the best available original document. 


\title{
DESIGN PROGLEMS OF A CONTINUOUS INJECTOR OF \\ MANY AMPERES OF MEV DEUTERIUM NEUTRALS
}

\author{
BY \\ Joel H. Fink \\ Lawrence Livermore Laboratory, University of California \\ Livermore, California 94550 \\ October, 1976

\section{ABSTRACT}

A continuous injector of many amperes of MeV deuterium neutrals, will require high currents of negative deuterium ions to be generated, accelerated and stripped of electrons by methods that are not fully developed. Each of these processes as briefly described in this report, introduce constraints upon the ion optics, beam line pumping, and high voltage stand-off that must be mutually resolved. Although the design of such an injector represents a difficult task, there is no fundamental reason that very high current beams cannot be handled.

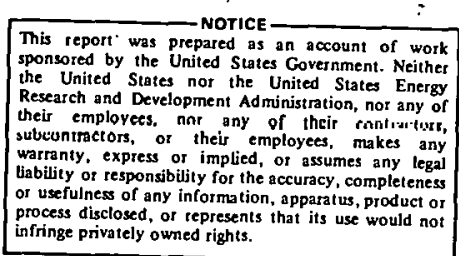

This report was prepared as an account of work the United Siotes nor the Uniternment. Neithet Research and Development Administration, nor any of subcontractors, or any of their raritrattors, ability, express or implied, of assumes any legal or usefulness of any infringe privately owmed rights. 


\section{DESIGN PROBLEMS OF A CONTINUOUS INJECTOR OF \\ MANY AMPERES OF MEV DEUTERIUM NEUTRALS}

by

Joel H. Fink

\section{Introduction}

As the most intense proton injectors on 1 ine today ${ }^{11}$ are capable of delivering a couple of hundred milliamperes at $750 \mathrm{keV}$, a continuous injector of several amperes of neutral deuterium at one-MeV is beyond the state of the art. To obtain a reasonable output, high currents of negative deuterium ions must be generated, accelerated and stripped of electrons by methods that are not fully developed.

Although the problems to be resolved are difficult, there is no fundamental reason that high current beams cannot be handled. As a consequence the ultimate performance of such an injector is limited only be the inventiveness of the people who design them.

\section{The Ion Source (see Figure 1)}

Because their neutralization efficiency falls off so rapidly with increasing energy, positive ions are not a practical source of 1-MeV neutrals ${ }^{3}$. Negative ions must be used.

For satisfactory system performance, it is important that the negative ion source does not overburden the injector with a poor gas efficiency that creates pumping problems, with a high precentage of electrons in the negative jon beam that introduces a useless power drain, and with intense U.V. radiation that can cause electron emission from exposed electrodes. Furthermore, the source must provide a focusable beam. 
Unfortunately, a good source does not exist, although the Cesium double charge-exchange cell, under development at Livermore, offers promise to be the source for this application ${ }^{1,5}$ if only because the Cesium cell acts as a gas curtain between the high pressure region of ion extraction and the low pressure required in the neighborhood of ion acceleration. None of the other high current sources of negatives ions, such as the Hollow Discharge Duoplasmatron, ${ }^{7}$ or the Magnetron ${ }^{9}$ offer the prospect of long continuous operation, good gas efficiency, etc. (see table l).

However there are other ideas worthy of investigation. 0. A. Anderson's proposa $7^{2}$ to use the interaction of a gas jet with a cesiated tungsten surface, in accordance with J. R. Hiskes' theory, ${ }^{6}$ is of interest, while. K. W. Ehler's suggestion, ${ }^{12}$ calling for the use of clusters as a source of neutrals, should be investigated.

\section{The Accelerator Column}

In the accelerator column a conflict exists between the requirements of ion optics, pumping and reliable high-voltage stand-off. These are discussed below.

An accelerator designed in accordance with a Pierce Column, has a voltage variation along the bcam path which follows Child's Law, i.e.

$$
V=(J / g)^{2 / 3} z^{4 / 3}
$$

in which $\mathrm{g}$ is the system perveance. Thus for an assumed ion beam current density of $30 \mathrm{~mA} \mathrm{~cm}{ }^{-2}$, the result is:

$$
V=\left(8 \times 10^{3}\right) Z^{4 / 3}
$$

This shows that a minimum length of $37 \mathrm{~cm}$ is required to house a sequence of grids to accelerate a deuterium ion beam to $1 \mathrm{MeV}$. 
Gas escaping from the negative ion source is transported through the accelerator. Depending upon how this gas is pumped away, there can be a wide range of background gas densities. From crude estimates it can be shown that the fraction of negative ions in the beam that are lost by charge-exchange with the background gas will range for 4 to $24 \%$, depending upon the gas efficiency of the source, and upon whether the pumping is done only at the end of the accelerator, or transverse to the beam line through the gaps between successive grids. (see Figures 2 and 3 )

Although such a beam loss is undesirable, it is the stripped electrons left in the wake of the beam that create the serious problems when they ionize the background gas, bombard and pit electrodes, emit $X$-rays and generate more electrons via secondary emission. While the contours of the electrodes can be made to minimize these effects, the electron current loading will be high. Therefore the only solution to these problems is to maintain a low background gas density. Thus an ion source of good gas efficiency is essential, along with effective pumping along the accelerator column.

Pumping normal to the beam axis becomes less effective the larger and more dense the beam. Thus multiple aperture grids must be used with the beamlets adequately spread out. Furthermore, as the insertion of individual pumps at various potentials between the individual grids would lead to an ungainly configuration, it is necessary to place the entire beam line, electrodes, insulators and all, into an evacuated chamber. As a consequence other difficulties arise.

It is acknowledged in high voltage technology that there is always some probability of a voltage breakdown. (In fact the literature of high voltage proton injectors gleefully report designs in which arc-overs 
occur only once every few hours.) Thus the art is to limit the intensity of such discharges, and prevent them from doing permanent damage. This is done by crowbarring, etc., and by limiting the energy stored between adjacent electrodes. As a consequence there is a severe limit on the capacitance in the circuit, the capacitance between the grids and the inter-electrode potentials. The limited grid capacitance, restricts their useful area, which with a specific ion beam current density, establishes a maximum allowable beam current.

To get the best performance, proton injectors have the grids in the accelerator column sealed and mounted on ceramic rings with their circumferences exposed to air. No surrounding electrostatic shield are used, and only the exposed distributed capacitance adds to that of the internal grid system, and to that of the circuit. Thus to prevent breakdown in air, the accelerator is limited to less than one MeV. This is desirable ${ }^{13}$ as the open construction permits easy access to the ion source for maintenace.

Introducing the accelerator "column into an evacuated chamber will create problems of stored energy. To reduce the probability of breakdown, several metal. screens, with holes in them to facilitate pumping, must be introduced, at various potentials, to separate the high voltage elements from the grounded outer container wal1. So as to 1 imit the interelectrode capacitance, each successive screen must be separated by larger and larger. spacings which results in an immense structure. (see Figure 4)

W. Baker at. Berkeley has recently introduced what he calls "stacked cores" about the high current leads into the ion sources. 8 These are designed to dissipate energy in the event of a high current pulse in the wire passing through them. Thus the core acts as a dissipative load to a fast pulse, which dissappears with a sustained current. With the aid of 
a desaturation windings, the core can be unsaturated and prepared for any successive arc. Obviously the application of this feature to the accelerator column will be very beneficial, in that it dissipates the energy stored in the power supply and permits the energy stored in the shields and grids to be larger than otherwise. However it is proposed to also use this principle in the design of the electrostatic shields. If the arc current flowing through any portion of a shield is made to pass through many such cores, distributed around the shield surface, much of the stored energy would be dissipated, making the intensity of a discharge less sensitive to the size of the electrodes. (see Figure 5)

So far the structures considered are over simplified in that no allowance has been given for high voltage feed-throughs or to the prospect of using several pumping chambers in series, each insulated, at high voltage, from its neighbor. There is also the possibility of using other types of accelerators, such as a LINAC, because of their greatly reduced high voltage requirements. However direct acceleration entails a minimum accel gap length, so that the extended ion beam paths encountered in other accelerators require more effective pumping and lower background pressures to minimize charge-exchange, etc. Never-the-less, some combination of direct acceleration and a pulsed gap may be advantageous.

4. Neutralization Cell (see Figure 6)

Stripping the extra electron from negative ions can be done by several means, of which a gas or vapor cell is most convenient. 3 Actually at this high energy only a metal vapor cell, of Lithium for instance, need be considered because a gas cell will either put an unreasonable burden on the pumping system or be impossibly long. As a consequence $62 \%$ of a $1 \mathrm{MeV}$ negative ion beam can be gotten as neutrals from such a cell. 
However, at this energy the recovery of the power in the remaining $38 \%$ of the heam, or for that matter its disposal, is not a trivial exercise. The un-neutralized portion of the beam leaving a cell of optimum thickness is equally divided between positive and negative ions. Thus the two species must be separated for energy recovery and collected upon electrodes, one of which is plus and the other minus 1-MV relative to the beam potential.

With the sacrifice of 10 to $20 \%$ of the neutral output however, it is possible to use an overdose cell from which the un-neutralized beam is predominantly positive ions.

To obtain a high yield of neutrals photodetachment might be considered. 5 The power need of an optical cell, that is the power required to illuminate the cell per watt of output neutral beam is

$$
P_{N}=\frac{184 R}{D^{\circ} V_{0}^{1 / 2}} \text { in } \frac{1}{1-n_{N}}
$$

where $R$ is the beam radius, $D^{\circ}$ the neutral beam and $n_{N}$ the neutralization efficiency. Thus to neutralize $95 \%$ of a $4 \mathrm{~A}$ beam of $5 \mathrm{~cm}$ radius, $69 \%$ of the power of the neutral beam is required.' Obviously the power requirements of such a small beam are prohibitive.

Another method of obtaining a large percentage of neutralization is with a highly ionized plasma, in which the plasma electrons do the stripping. Dimov ${ }^{4}$ has shown that $82 \%$ of a $.5 \mathrm{MeV} \mathrm{H}^{-}$beam, corresponding

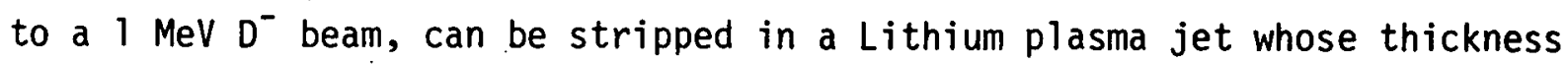
corresponds to $2 \times 10^{15}$ electrons per $\mathrm{cm}^{2}$. It is expected that the power requirements of such a cell will be reasonable, but the problem of what to do with the un-neutralized portion of the beam, remains. 


\section{Conclusions}

To obtain one MeV neutral deuterium injection it will be necessary to go through a broad development program of which the following are just a few of the required steps.

a) Develop a source of negative ions

b) Evaluate the effectiveness of core-stack shielding to minimize the seriousness of high-voltage vacuum arcs. Analyse the gas flow in an accelerator column to determine the most favorable pumping configuration and the resultant background gas density. Do computer studies to determine the most favorable electrode configuration with respect to electron bombardment.

c) Study the energy recovery designs for the neutralizer cell.

f) Begin work on the Power Supplies. It has been assumed that as the physics of 1-MV Power Supply, controls and arc suppressors is well known, 10 techniques can be developed to cope with the high currents required in this application. 


\section{$\underline{\text { References }}$}

10. A. Anderson, "A Compact High Energy Neutral Beam System" UCID-16914, (1975).

20. A. Anderson, "Efficient Energetic Neutral Beam Source Using Surface Conversion ( $D^{\circ}$ to $\left.D^{-}\right)$of a Jet" UCID-17282 (1976).

${ }^{3}$ K. H. Berkner, R. V. Pyle, J. W. Stearns, "Intense, Mixed-Energy Hydrogen Beams for CTR Injection" Nuclear Fusion Vo1. 5, p. 249 (1975).

${ }^{4}$ G. I. Dimov, G. V. Roslyakov, "Conversion of a Beam of Negative Hydrogen ions to Atomic Hydrogen in a Plasma Target at Energies Between 0.5 and 1 MeV" Nuclear Fusion, Vol. 15 p. 551 (1975).

5. H. Fink, W. L. Barr, G. W. Hamilton, "A Study of Efficient High Power, High Energy Neutral Beams for the Reference Mirror Reactor" UCRL in print (1976).

6j. R. Hiskes, "A Mechanism for Negative Ion Production in a Surface Plasma Negative Hydrogen Ion Source" UCRL-76650 (1976).

${ }^{7}$ M. Kobayashi, K. Prelec, Th. Sluyters, "Studies of the Hollow Discharge Duoplasmatron" BNL-21520 (1976).

${ }^{8}$ W. Baker, "Transformer Core Resistive Snubber for T.S. IIB", UCID-3872 (1975).

b) W. R. Baker, "Stored Energy and the LBL Neutral Beam Source" UCID-3871 (1976).

${ }^{9} \mathrm{~K}$. Prelec, Th. Sluyters, "Development of Intense Negative Hydrogen Ion Source at BNL" Proceedings of the Second "Symposium on Ion Sources and Formation of Ion Beams" Berkeley CA, VIII-6-1, (1974). 
${ }^{10}$ C. Reinhold, R. Gleyrod, "Megawatt HV D.C. Power Supplies" IEEE Transactions on Nuclear Science, Vol. N.S.-22, \#3 p. 1289 (1975).

${ }^{11}$ Th. Sluyters, R. Amari, V. Kovarik, R. Lockey, S. Senator, "A Bright High-Gradient $750 \mathrm{keV}$ Ion Gun" Particle Accelerators, Vol. 1, p. 15 (1970).

12 K. W. Ehlers, "Efficient, High Current Negative Ion Neutral Beam System" Lawrence Berkeley Laboratory Internal Communication. October 1976

13J. R. Blewett, "Linear Accelerators and Injection Techniques," Proceedings of the CERN Symposium on High Energy Accelerators and $P_{\text {ion }}$ Physics, Vol. 1, p. 161, (1956). 
TABLE I

PERFORMANCE OF NEGATIVE ION SOURCES

\begin{tabular}{|c|c|c|c|c|}
\hline Performance & $\begin{array}{l}\text { Hollow } \\
\text { Discharge Duo- } \\
\text { Plasmatron }\end{array}$ & Magnetron & $\begin{array}{l}\text { Cesium } \\
\text { Double-Charge- } \\
\text { Exchange cell }\end{array}$ & $\begin{array}{c}\text { Jet } \\
\text { source }\end{array}$ \\
\hline Gas Efficiency & Good & Poor & Good & Excellent \\
\hline Optical Quality of Beam & Good & Poor & $?$ & ? \\
\hline $\begin{array}{l}\text { Prospect of Continuous } \\
\text { Operation }\end{array}$ & Fair & Good & Excellent & Excellent \\
\hline $\begin{array}{l}\text { Extracted Current } \\
\text { Pulse Length } \\
\text { Electron Component } \\
\text { in Beam }\end{array}$ & $\begin{array}{l}60 \mathrm{~mA} \\
1 \mathrm{mS} \\
\text { High }\end{array}$ & $\begin{array}{l}1 \mathrm{~A} \\
2 \mathrm{mS} \\
\text { Low }\end{array}$ & $\begin{array}{r}200 \mathrm{~mA} \\
25 \mathrm{mS} \\
\text { Low }\end{array}$ & $\begin{array}{c}? \\
\text { None }\end{array}$ \\
\hline
\end{tabular}


A. Hollow Discharge Duoplasmatron (Ref. 7)

B. Magnetron (Ref. 9)
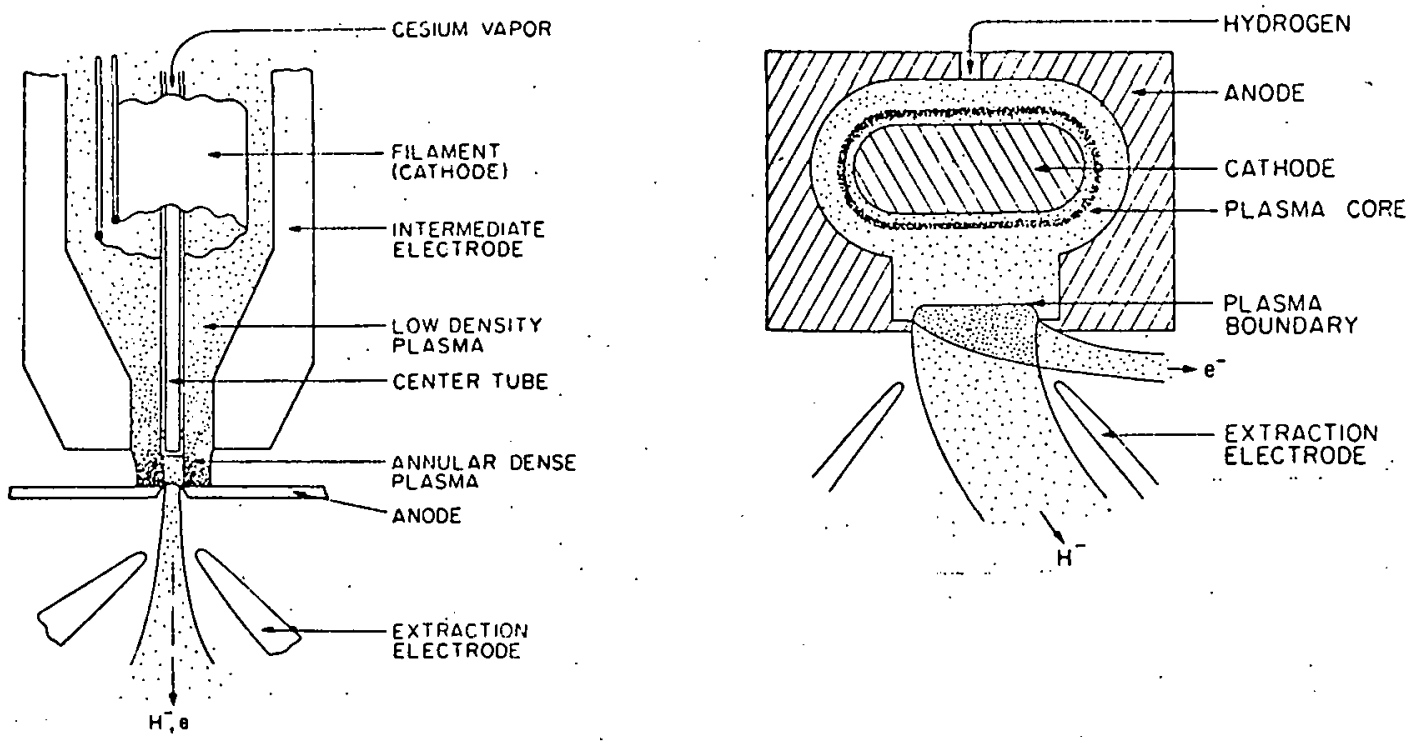

C. Cesium Double Charge-Exchange Cel1 (Ref. 5)

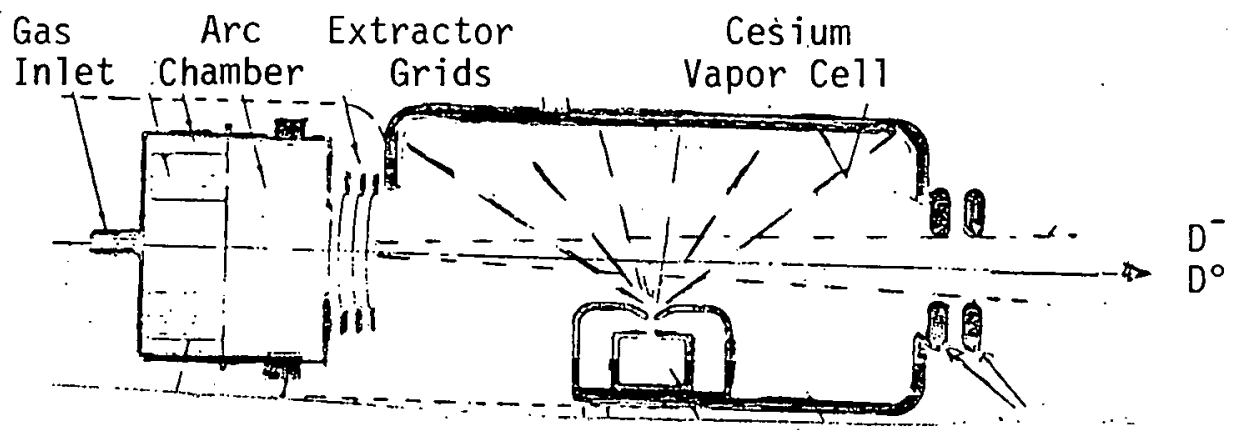

Initial Accel Grids

D. Jet Source (Ref: 2)

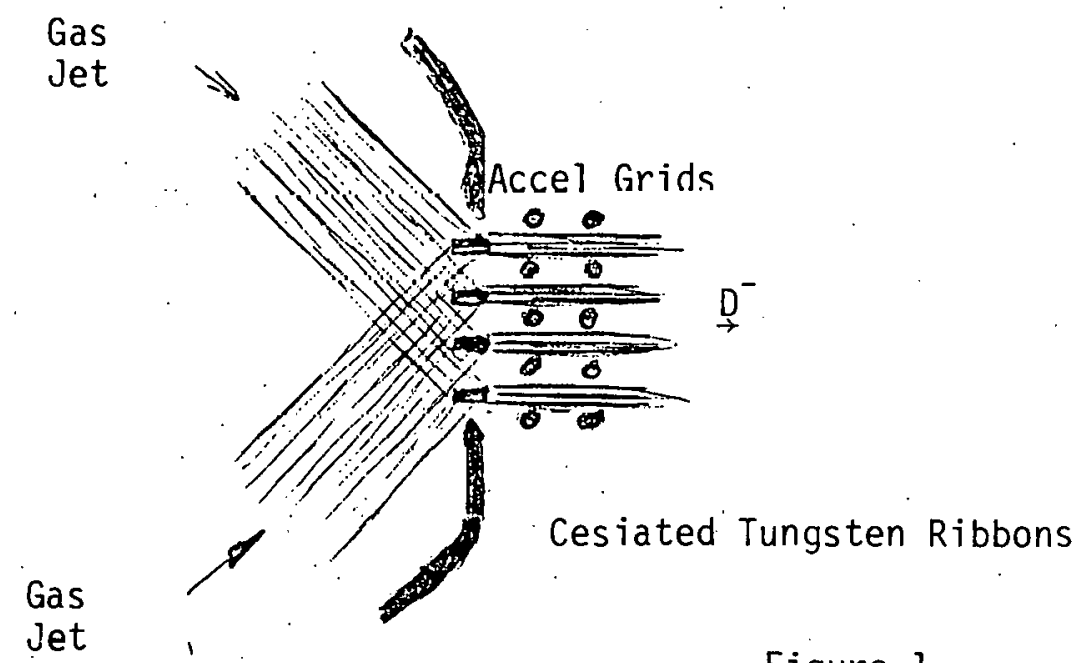

Figure 1 


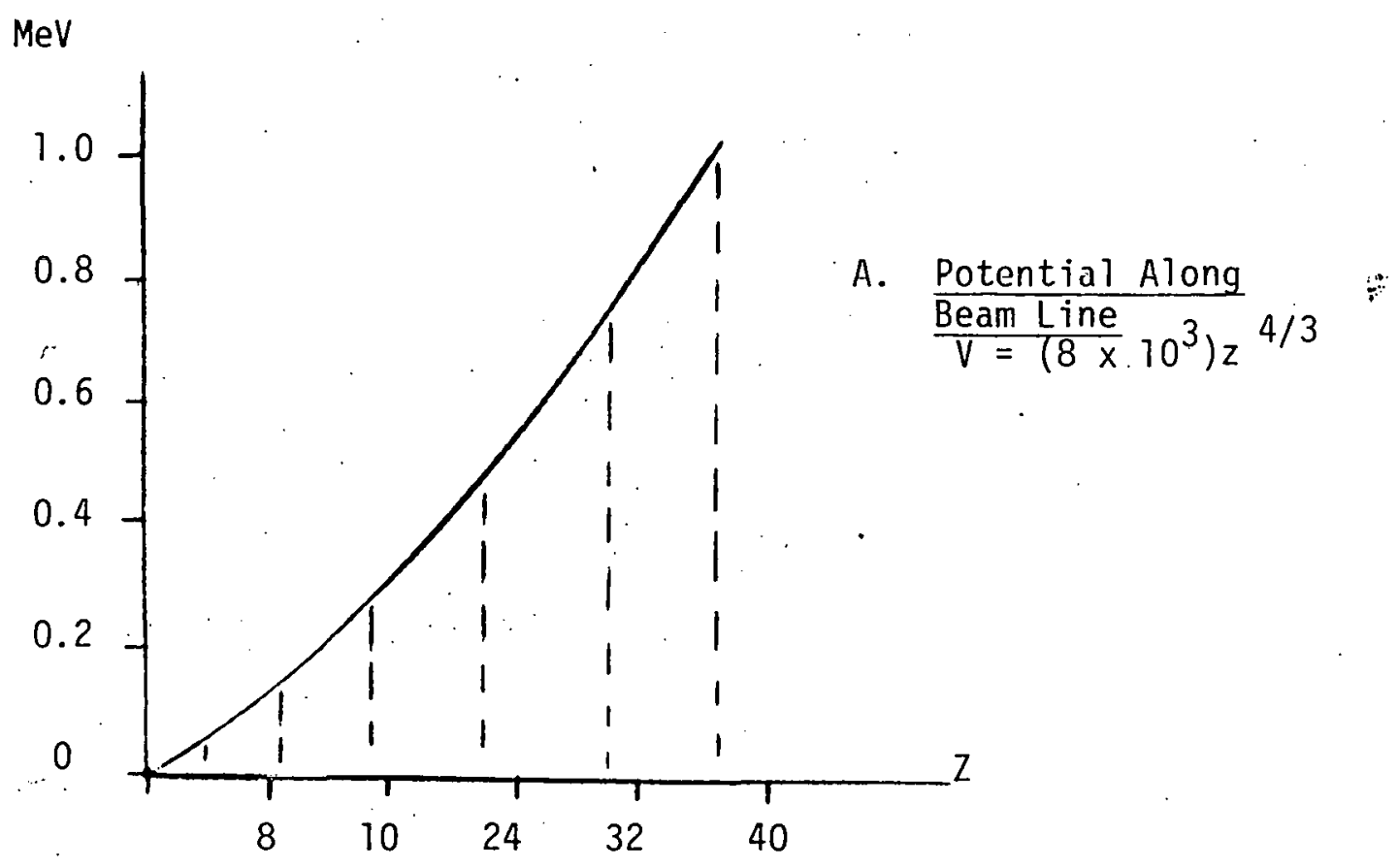

B. Beam Line Schematic

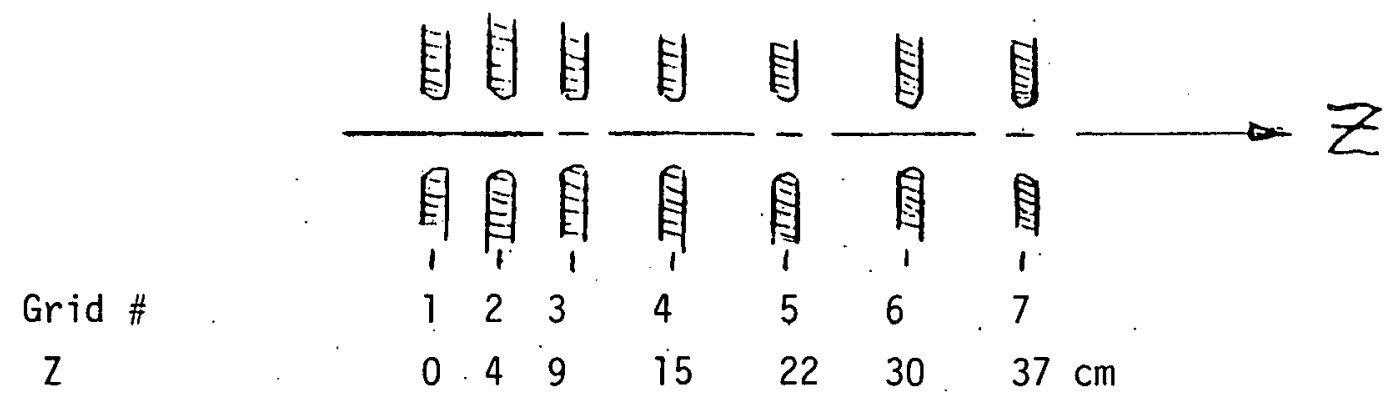

C. Pressure Along Beam Line

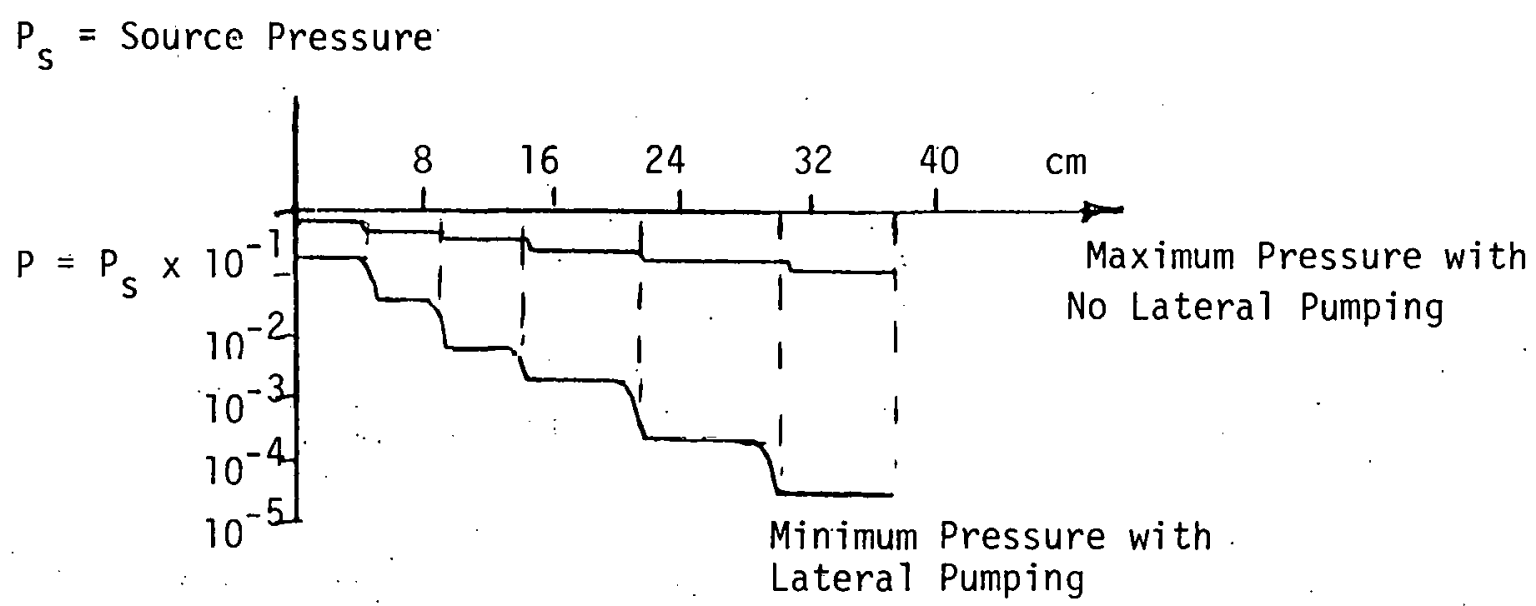

Figure 2 

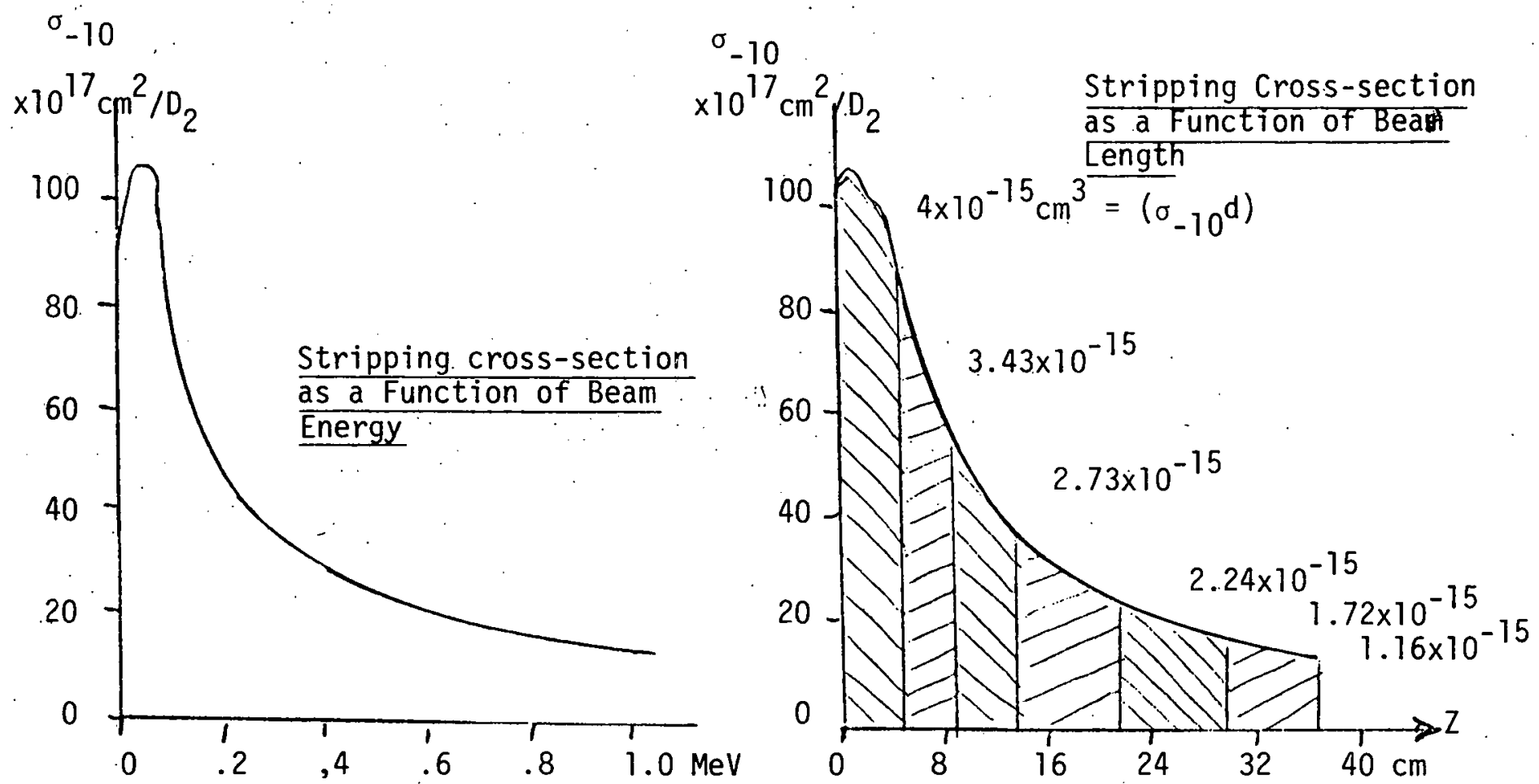

Stripping Fraction as a Function of Source Pressure

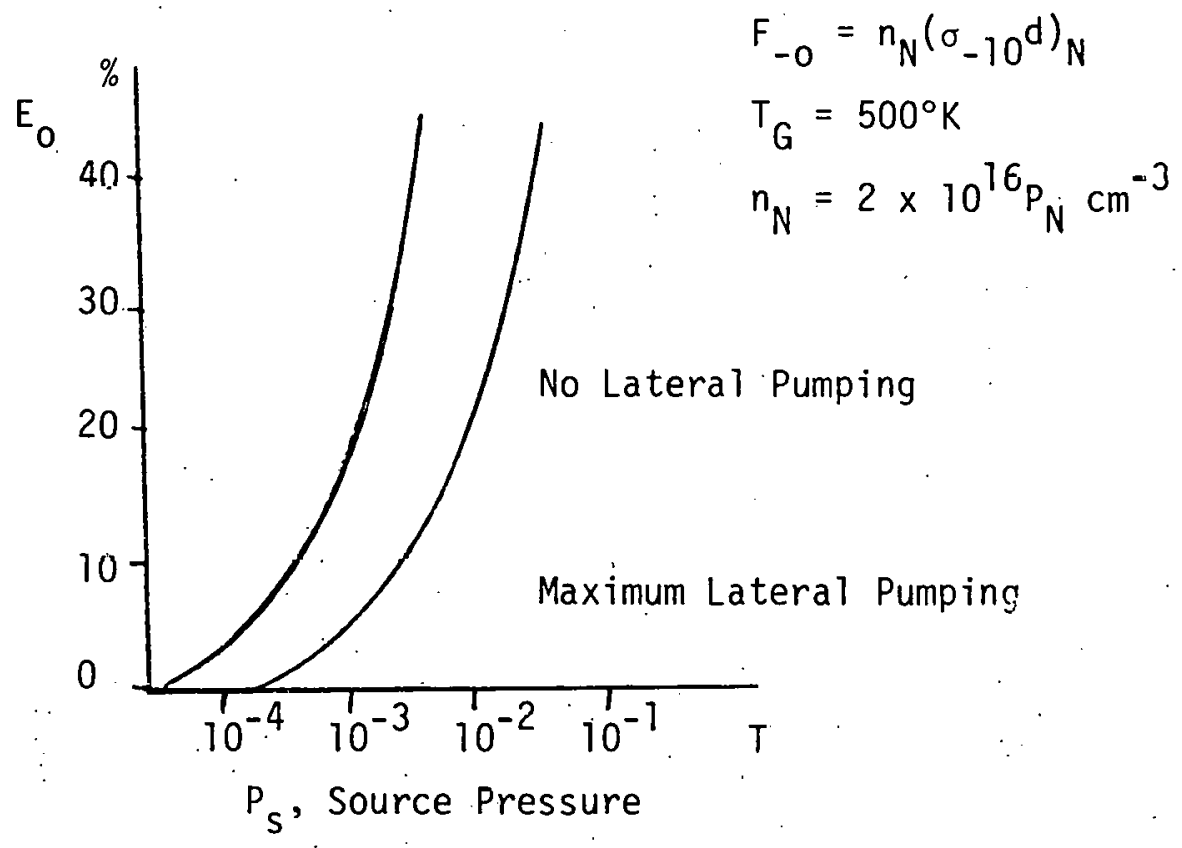

Figure 3 


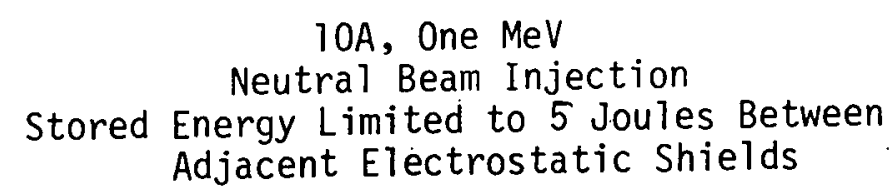

10A, One MeV
Neutral Beam Injection

Adjacent Electrostatic Shields

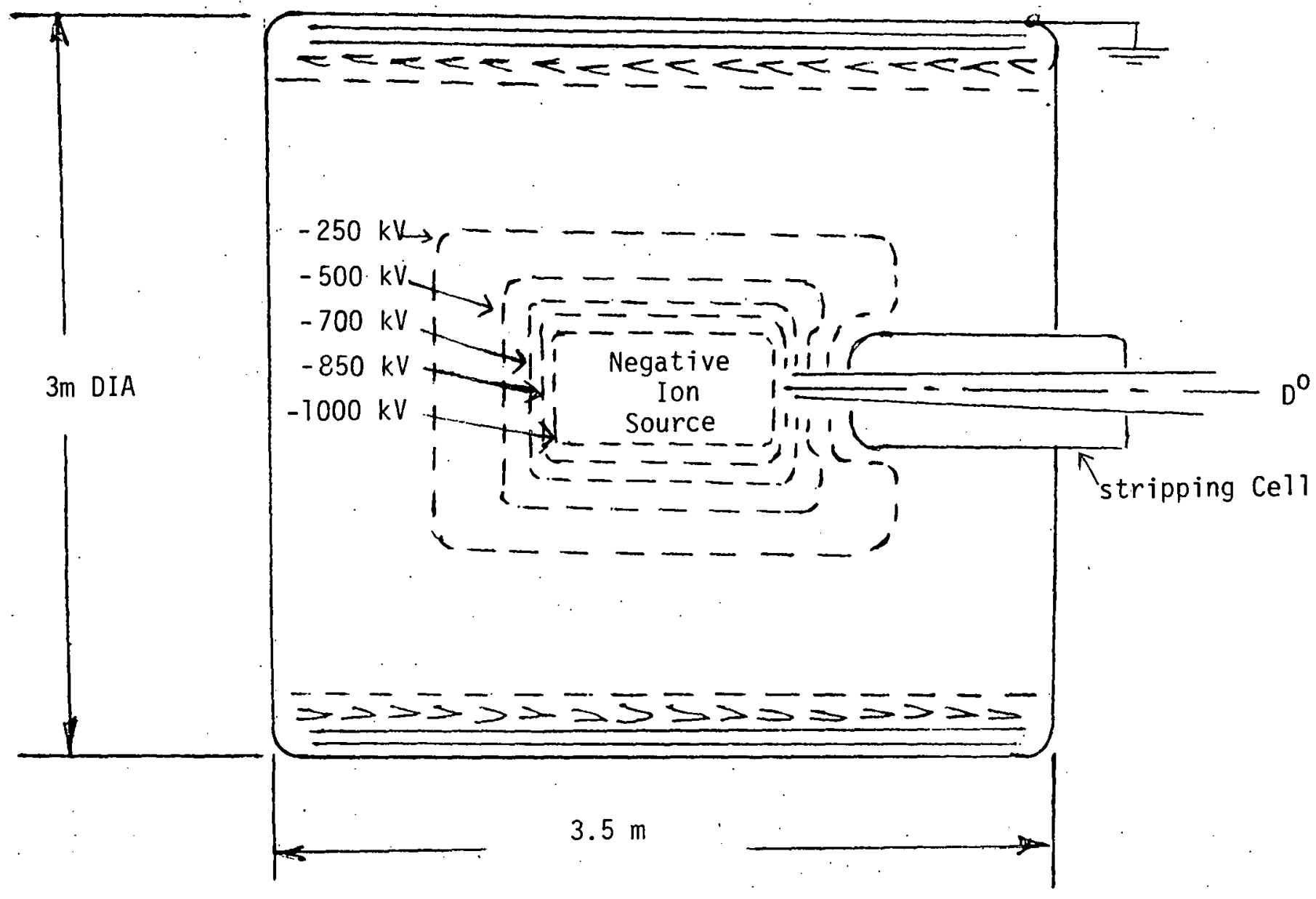

Figure 4 

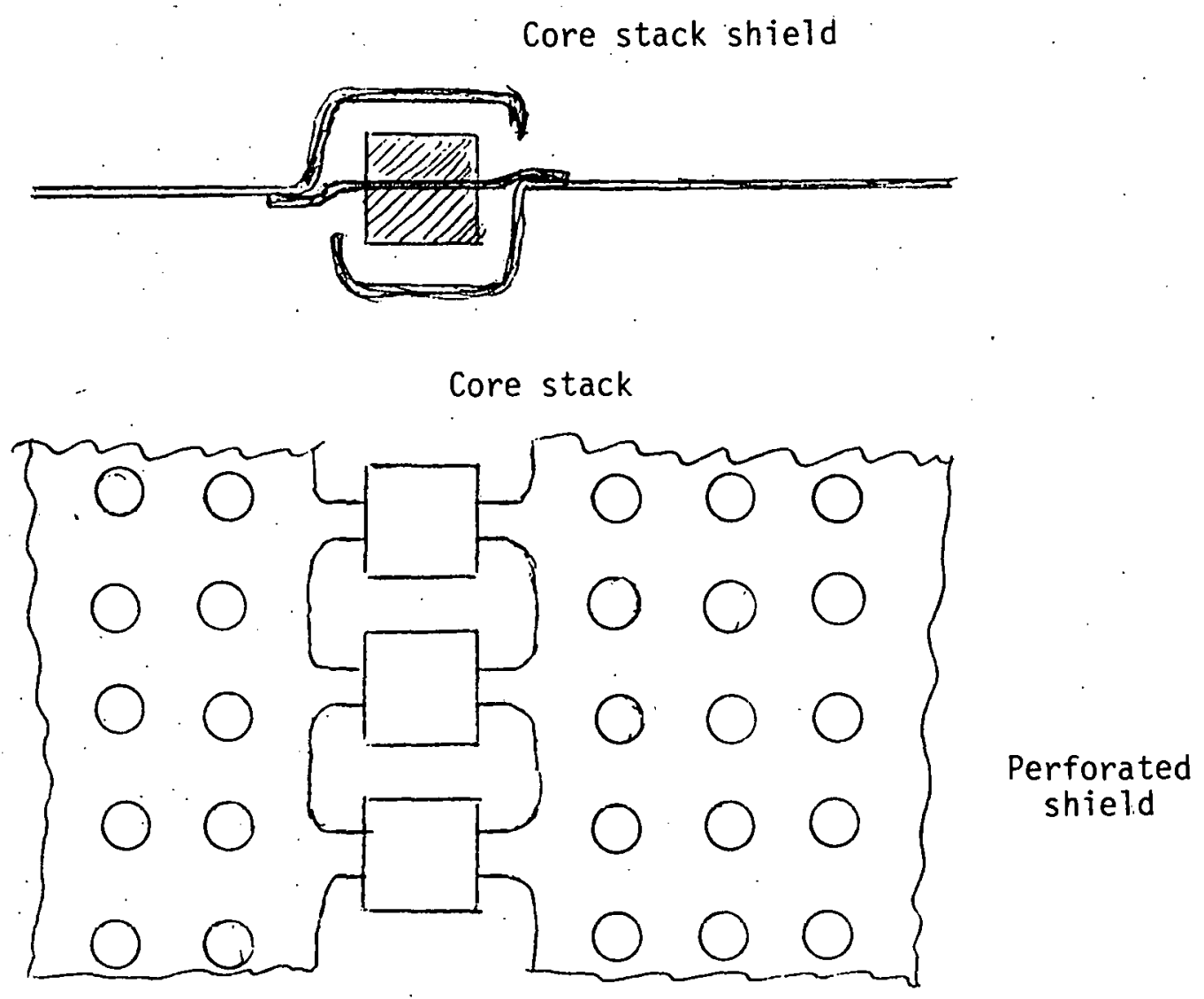

Figure 5 


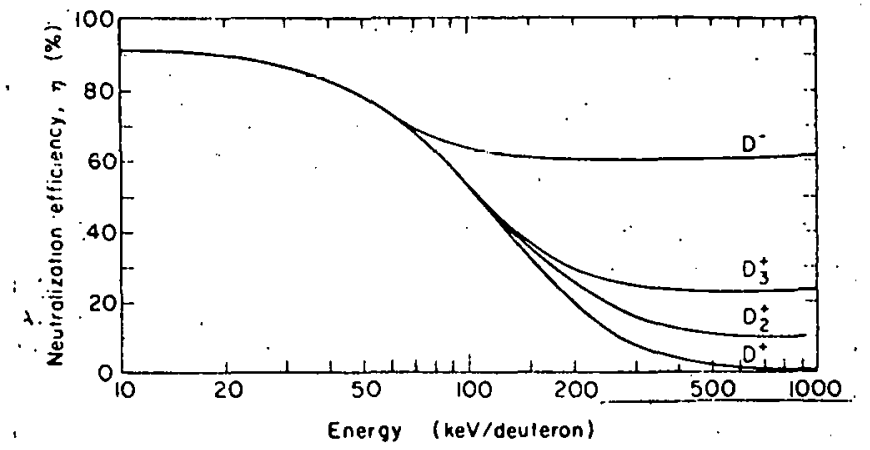

A. Gas or Vapor Cell (Ref. 3)

$\pi_{\max }=2 \times 10^{16} \mathrm{~cm}^{-2}$

Efficiency, $n_{N}=62 \%$.

B. Photodetachment Cell (Ref. 5)

(4A Beàm, $10 \mathrm{~cm}$ DIA)

Required Power $=0.69$ Beam Power

Efficiency, $n_{N}=95 \%$
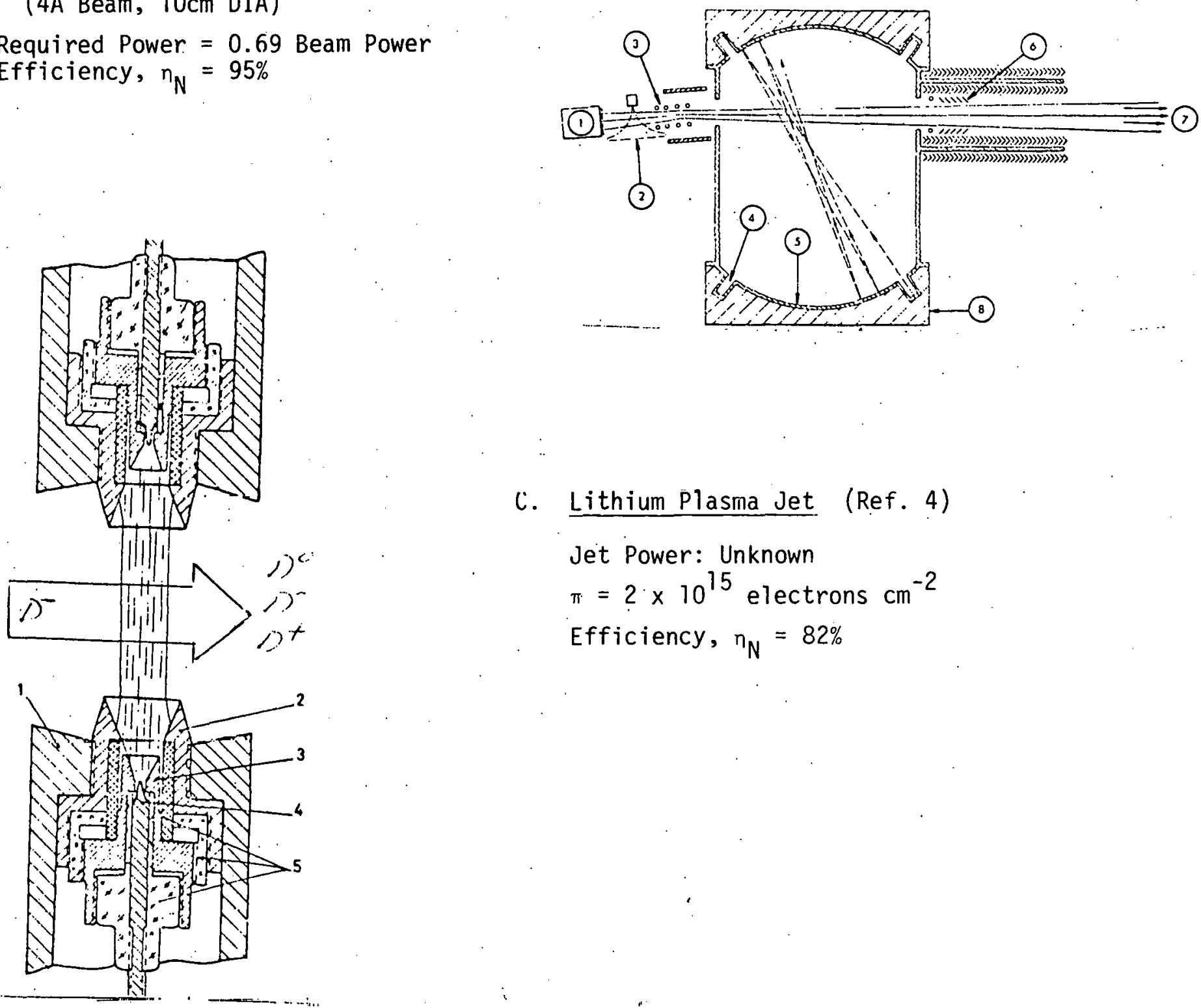

c. Lithium Plasma Jet (Ref. 4)

Jet Power: Unknown

$\pi=2 \times 10^{15}$ electrons $\mathrm{cm}^{-2}$

Efficiency, $\eta_{N}=82 \%$ 
Internal Distribution

C. E. Taylor L-386

0 . A. Anderson $L-387$

T. K. Fowler (5) L-382

W. L. Barr L-386

C. C. Damm L-386

G. W. Hamilton L-387

J. R. Hiskes L-388

E. B. Hooper, Jr. L-387

B. G. Logan L-386

R. W. Moir L-386

J. E. Osher I. L-386

R. F. Post L-386

D. S. Prono $\mathrm{L}-387$

J. W. Shearer L-387

R. W. Kuenning L L-728

T. Batzer L-383

D. Bender L-383

G. Carlson L-383

F. H. Coensgen (2) L-382

W. C. Condit : L-386

D. Cornish L-384

J. Doggett L-384

J. H. Fink (20) L-387

TID (15) L-9
External Distribution

R. V. Pyle, K. Ehlers,

W. Baker, K. Berkner

W. Cooper

Lawrence Berkeley Laboratory

No. 1 Cycltron Road

Berkeley, CA 94720

Th. Sluyters, K. Prelec

M. W. Grossman

Brookhaven National Laboratory Associated Universities, Inc. Upton, N.Y. $\quad 11973$

R. D. Haun, Jr. , C. K. Jones Westinghouse $R$ \& $D$ Center 1310 Beulah Road Pittsburgh, PA 15235

Z. Shapiro, D. Klein Westinghouse Electrice Corp. Nuclear Energy Sys tems Box 355a

Pittsburgh, PA, 15230

TIC, Oak Ridge 


\section{NOTICE}

This report was prepared as an account of work sponsored by the United States Government. Neither the United States nor the United States Energy Research \& Development Administration, nor any of their employees, nor any of their contractors, subcontractors, or their employees, makes any warranty, express or implied, or assumes any legal liability or responsibility for the accuracy, completeness or usefulness of any information, apparatus, product or process disclosed, or represents that its use would not infringe privately-owned rights.

\section{NOTICE}

Reference to a company or product name does not imply approval or recommendation of the product by the University of California or the U.S. Energy Research \& Development Administration to the exclusion of others that may be suitable.

Printed in the United States of America Available from

National Technical Information Service

U.S. Department of Commerce

5285 Port Royal Road

Springfield, VA 22161

Price: Printed Copy $\$$ : Microfiche $\$ 3.00$

\begin{tabular}{|c|c|c|c|}
\hline Page Range & $\begin{array}{c}\text { Domestic } \\
\text { Price }\end{array}$ & Page Range & $\begin{array}{c}\text { Domestic } \\
\text { Price }\end{array}$ \\
\hline $001-025$ & \& 3.50 & $326-350$ & 10.00 \\
\hline $026-050$ & 4.00 & $351-375$ & 10.50 \\
\hline $051-075$ & 4.50 & $376-400$ & 10.75 \\
\hline $076-100$ & 5.00 & $401-425$ & 11.00 \\
\hline $101-125$ & 5.50 & $426-450$ & 11.75 \\
\hline $126-150$ & 6.00 & $451-475$ & 12.00 \\
\hline $151-175$ & 6.75 & $476-500$ & 12.50 \\
\hline $176-200$ & 7.50 & $501-525$ & 12.75 \\
\hline $201-225$ & 7.75 & $526-550$ & 13.00 \\
\hline $226-250$ & 8.00 & $551-575$ & 13.50 \\
\hline $251-275$ & 9.00 & $576-600$ & 13.75 \\
\hline $276-300$ & 9.25 & 601-up & * \\
\hline & & & \\
\hline
\end{tabular}

*Add $\$ 2.50$ for each additional 100 page increment from 601 to 1,000 pages add $\$ 4.50$ for each additional 100 page increment over 1,000 pages. 
Technical Information Department

LAWRENCE LIVERMORE LABORATORY

University of California | Livermore, California | 94550 